\title{
Pkd2 deletion during embryo development does not alter mesonephric programmed cell senescence
}

\author{
SABELA DA SILVA-ÁLVAREZ', OLAYA LAMAS-GONZÁLEZ², ALBA FERREIRÓS'1 , PATRICIA GONZÁLEZ, \\ MARÍA GÓMEZ ${ }^{3}$, TOMÁS GARCÍA-CABALLERO ${ }^{3}$, MIGUEL GONZÁLEZ BARCIA4, \\ MIGUEL A. GARCÍA-GONZÁLEZ*,2 and MANUEL COLLADO*,1
}

\begin{abstract}
'Laboratorio de Células Madre en Cáncer y Envejecimiento, Instituto de Investigación Sanitaria de Santiago de Compostela (IDIS), XXIS/SERGAS, ${ }^{2}$ Laboratorio de Genética y Biología del Desarrollo de las Enfermedades Renales, Instituto de Investigación Sanitaria (IDIS), XXIS/SERGAS, ${ }^{3}$ Histopathology Core Unit, Spanish National Cancer Research Centre (CNIO), Madrid, ${ }^{4}$ Departamento de Ciencias Morfológicas, Facultad de Medicina. USC. XXIS/SERGAS, ${ }^{5}$ Servicio de

Farmacia, Xerencia de Xestión Integrada de Santiago (XXIS/SERGAS), Santiago de Compostela, Spain
\end{abstract}

\begin{abstract}
Programmed cell senescence during embryo development is a recently described process that opens a new perspective to understand the senescence response and that adds a new player whose contribution to development needs to be addressed. Identifying developmental syndromes with a root in deregulated programmed cell senescence will undoubtedly reinforce our view of senescence and could provide a new angle to confront disease. One of the structures that was initially reported to undergo cellular senescence is the mesonephros. During E12.5-E14.5, before regression, mesonephric tubules are positive for the most widely used marker of cell senescence, SA $\beta$ G, and negative for proliferation marker, Ki67, in a p21Cip1-dependent manner. PKD2 is one of the genes defective in autosomal dominant polycystic kidney disease (ADPKD). Inherited mutations in this gene result in cyst formation in adults after a secondary hit. Polycystin-2 (PC2) protein, the product of PKD2 gene expression, inhibits cell cycle progression by inducing p21Cip1, whereas mutated PKD2 results in increased proliferation and defective differentiation of kidney epithelial cells. Here, we addressed the possibility of defective programmed cell senescence as a consequence of $\boldsymbol{P k d} 2$ deletion in mice. We analyzed embryos for the expression of the senescence marker SA $\beta$ G, for the proliferative status of mesonephric tubule cells, and for the expression of p21Cip1, without identifying any noticeable deregulation of cell senescence. Our results exclude defective programmed cell senescence upon Pkd2 ablation as an initial event in ADPKD.
\end{abstract}

KEY WORDS: Pkd2, cellular senescence, development, mesonephros

Cell senescence has been considered traditionally a stress response triggered to stop proliferation of cells after exposure to potentially dangerous stimuli (Collado and Serrano, 2010). This cell protective response is also linked to cellular aging as a result of the time dependent accumulation of senescent damaged cells in tissues (Collado et al., 2007). However, recently, programmed cell senescence was also described as part of the embryo development helping shape morphological structures by actively promoting cell population replacement in certain particular tissues and contributing to organ formation (Muñoz-Espín et al., 2013; Storer et al., 2013).
Among the different tissues and organs in which cell senescence has been identified, such as the endolymphatic sac of the inner ear, the closing of the neural tube, the vibrissae, or the apical ectodermal ridge, cell senescence is a contributing force for the kidney. The mesonephros is a transitory embryonic kidney acting before the maturation of the definitive kidney, or metanephros, and

\footnotetext{
Abbreviations used in this paper: ADPKD, autosomal dominant polycystic kidney
} disease; PC2, polycystin-2.

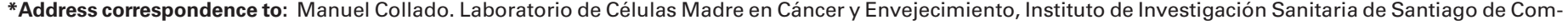

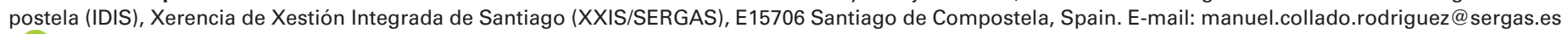
- iD https://orcid.org/0000-0002-0330-0880 or

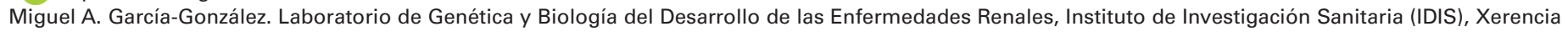
de Xestión Integrada de Santiago (XXIS/SERGAS), E15706 Santiago de Compostela, Spain. E-mail: miguel.garcia.gonzalez@sergas.es
} 
essentially disappearing at around E15.5 (Davidson, 2008). Before that, and starting at around E12.5, mesonephric tubules undergo cellular senescence: they are positive for senescence-associated beta-galactosidase (SA $\beta \mathrm{G}$ ) staining, the most widely used and accepted marker of cell senescence, and at the same time they are negative for the proliferation marker Ki67, and express cell cycle and senescence mediator p21Cip1 (the product of the Cdkn1a gene) (Muñoz-Espín et al., 2013). All these markers disappear at around $\mathrm{E} 15.5$, a time when mesonephric tubules are already hardly detectable. Deficiency in senescence mediator p21Cip1 strongly reduces the activity of $S A \beta G$ and rescues proliferation in the mesonephric tubules. However, the existence of redundant compensatory mechanisms based on apoptosis allows normal development to proceed, and senescence deficiency due to loss of $\mathrm{p} 21 \mathrm{Cip} 1$ only results in an increased incidence of vaginal septa that compromises the fertility of Cdkn1a-null female mice (MuñozEspín et al., 2013). Despite this relatively mild phenotype, defective senescence during embryo development is a plausible cause for syndromes with a developmental origin.

Autosomal dominant polycystic kidney disease (ADPKD) is the most prevalent monogenic human disorder and is characterized by bilateral renal tubular cyst formation and progressive enlargement (Gabow, 1993). ADPKD is associated with mutations mainly in PKD1 (responsible of ADPKD-Type I), with $80-85 \%$ of ADPKD families carrying mutations for this gene, and in PKD2 (-Type II), with $15-20 \%$ of patients carrying mutations in PKD2 (Cornec-Le Gall et al., 2017). Affected individuals carry germ line mutations in these genes, although cysts development does not occur until adulthood. Mouse models of $P k d 1$ and $P k d 2$ have been generated and, interestingly, complete deletion of $P k d 2$ results on cysts formation as early as E15.5, implying the existence of defects preceding this developmental stage caused by the absence of $P k d 2$ (Wu et al., 1998). One of the effects described for deficiency of $P k d 2$ is increased proliferation and branching morphogenesis in kidney epithelial cells (Grimm et al., 2006) and, indeed the overexpression of Polycystin-2 (PC2) protein encoded by $P k d 2$ leads to a cell growth arrest that is mediated by inhibition of Id 2 transcription factor (Li et al., 2005). Id2 is a positive cell cycle regulator that accumulates in the nucleus to promote proliferation and to regulate differentiation at least in part by suppressing p21 induction. It has been reported that PC2 modulates Id 2 by directly binding to Id 2 in a PC1-dependent manner (Li et al., 2005). In agreement with these observations, expression of both $\mathrm{PC} 1$ and $\mathrm{PC} 2$ reduces the cell cycle by blocking Id2 action over $\mathrm{p} 21$, and it has been described that PC1 overexpression induces p21 levels in MDCK cells in a PC2-dependent manner (Bhunia et al., 2002).

With all these previous knowledge, we decided to investigate whether $P k d 2$ deletion during embryo development in mice could result in a defective cellular senescence response in the mesonephros that could be the origin of cysts formation later on in the adult.

\section{Results}

In order to analyze the cell senescence response in Pkd2 deficient embryos we set up crosses of $P k d 2$ heterozygous animals. In this manner, we obtained littermate embryos of wild type (WT) and $P k d 2-n u l l ~ g e n o t y p e s$. We checked vaginal plugs the following day and estimated the gestational period of time. At E13.5 we sacrificed the pregnant mice, extracted the embryos, fixed them immediately
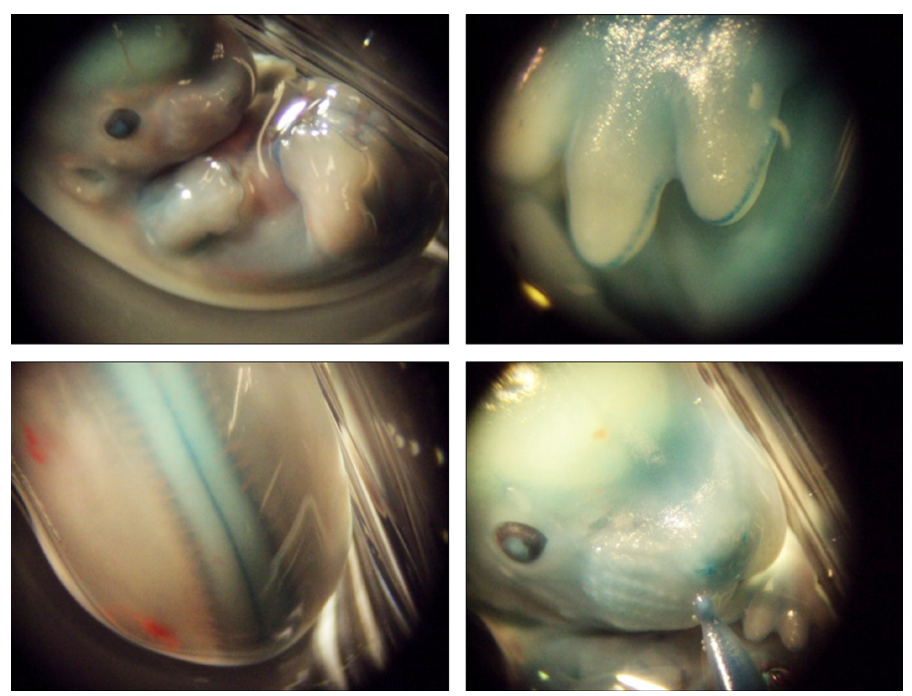

Fig. 1. Representative pictures of Pkd2-null embryos stained with SABG. Photographs under magnifying glass of a stained whole embryo, the fore limb showing the apical ectodermal ridge, the closing neural tube and vibrissae (from top to bottom and left to right).

in fixation solution, and whole mount-stained them by incubation in SA $\beta$ G staining solution overnight at $37^{\circ} \mathrm{C}$. Direct macroscopic inspection of stained $P k d 2$-null embryos showed positive reaction in the apical ectodermal ridge of the limbs, the closing of the neural tube or the vibrissae with similar intensity than the one observed for WT embryos (Fig. 1).

After staining, embryos were washed, dessicated in ethanol and embedded in paraffin. We sectioned these embryos and checked for the appearance of SA $\beta G$ stained areas in the embryos, corresponding to the endolymphatic sac and mesonephric tubules, as reported (Muñoz-Espín et al., 2013). Consecutive sections spanning the stained structures were further used for immunohistochemical analysis using antibodies specific for a proliferation marker, Ki67, and for the cell senescence and cell cycle inhibitor marker, p21Cip1. Sections from WT embryos showed a strong SA $\beta$ G blue positive staining in the endolymphatic sac (Fig. 2A), a structure that is part of the inner ear and that has been described to present a strong $S A \beta G$ staining at this time during development. The epithelium of this structure was concomitantly mainly negative for the proliferative Ki67 marker and positive for the cell senescence marker p21Cip1, validating our analysis. In the case of the Pkd2-null embryos we observed the exact same pattern, implying a normal cell senescence response in these embryos for this specific structure (Fig. 2A).

Next, we focused our attention on the mesonephros. This is an elongated structure, adjacent to the gonads, and longitudinally crossed by the mesonephric or Wolffian ducts, from which numerous lateral tubules emerge (Sainio, 2003; Vazquez et al., 1998). In contrast to the endolymphatic sac, the WT mesonephric tubules appear very weakly positive after whole-mount SA $\beta$ G staining with pale and punctuated blue dots surrounding the cells that are part of the tubules (Fig. 2B). These tubules were mainly negative for the proliferation marker, Ki67, and showed positive staining for p21Cip1 senescence marker, as reported previously. When $P k d 2-n u l l$ embryos were analyzed we observed the exact same pattern, with light but clear SA $\beta$ G staining, absence of proliferation 
as judged by lack of Ki67 staining, and positive p21Cip1 staining, suggesting a normal cell senescence response during embryo development of the mesonephros (Fig. 2B). We speculated with the possibility that a putative defective senescence could be observed at a later time point. For this, we repeated this same analysis in embryos at E14.5 obtaining essentially the same results (Fig. 2 $A, B)$, confirming that cellular senescence remained unaltered by deficiency of $P k d 2$ in the mouse.

\section{Discussion}

The recent description of senescence contributing to embryo development highlights the relevance of this crucial cellular response and offers another example of the parallelism between this process and apoptosis, both terminal cellular responses that can be triggered either by a stress response or upon developmental cues (MuñozEspín and Serrano, 2014; Pérez-Garijo and Steller, 2014). At this early stage, we can only speculate on the role played by cellular senescence during development. A powerful experimental approach to reveal the function of cellular senescence would be to cancel the process on animal models and observe the effect produced by its absence on the adult animal. Another alternative would be to identify a pathology associated with altered senescence during development. Given that ADPKD is a two-hit pathology originated already during development upon expression of a mutated $P k d 1$ or Pkd2 gene (Qian et al., 1996; Watnick et al., 1998), we wondered whether we could detect a deficient cellular senescence response in null embryos that could result in increased unscheduled proliferation and altered differentiation of the primitive embryonic kidney, and that could account for the defects that would eventually lead to the pathology in the adult.

Our global analysis of the senescence response did not show any altered pattern of SA $\beta$ G staining, nor of the expression of the proliferative marker Ki67 or of the senescence mediator p21. When we inspected in detail the presence of these markers in the mesonephros at two different time points, E13.5 and E14.5, the time at which cellular senescence has been described to contribute to kidney development, we could not observe any defects in the senescence response, confirming that cellular senescence is not altered by the absence of $P k d 2$.

The delicate regulation of a crucial process such as development would probably imply that gross defects will not be tolerated and, at the same time, alteration of senescence could be counterbalanced by other mechanisms, such as increased apoptosis. Despite this
A

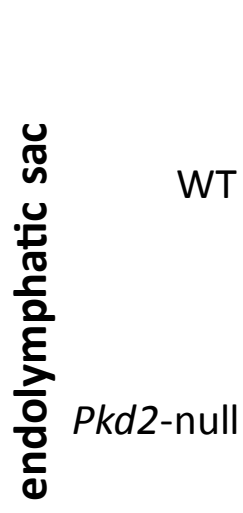

B

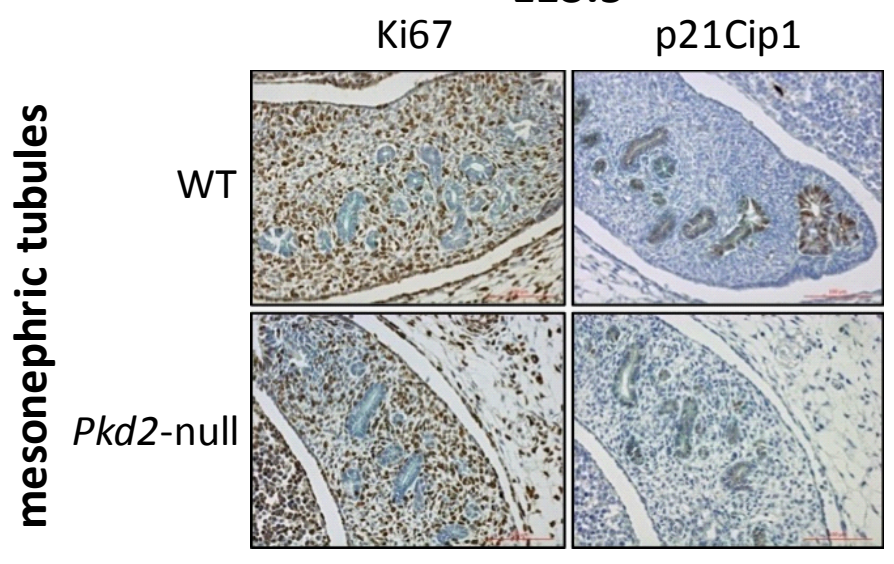

E13.5 p21Cip1

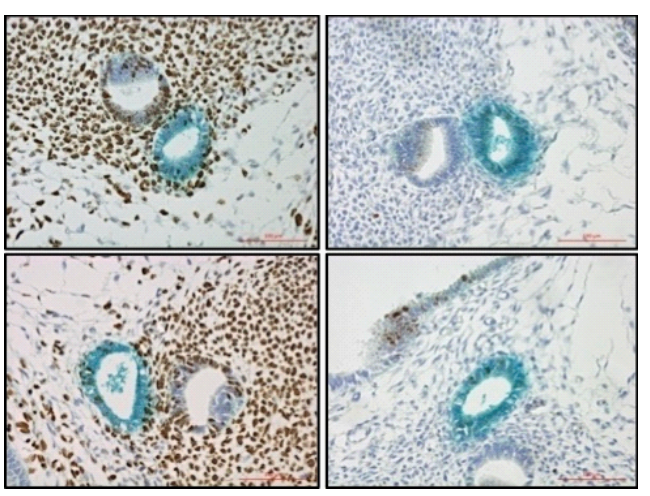

E13.5

Ki67

\section{E14.5}

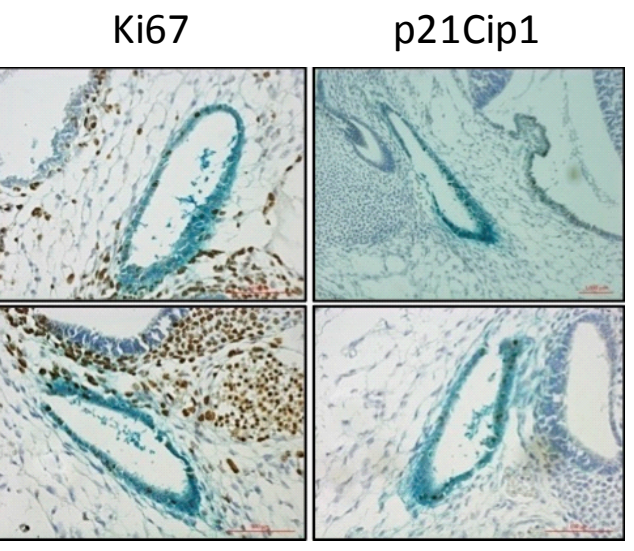

E14.5

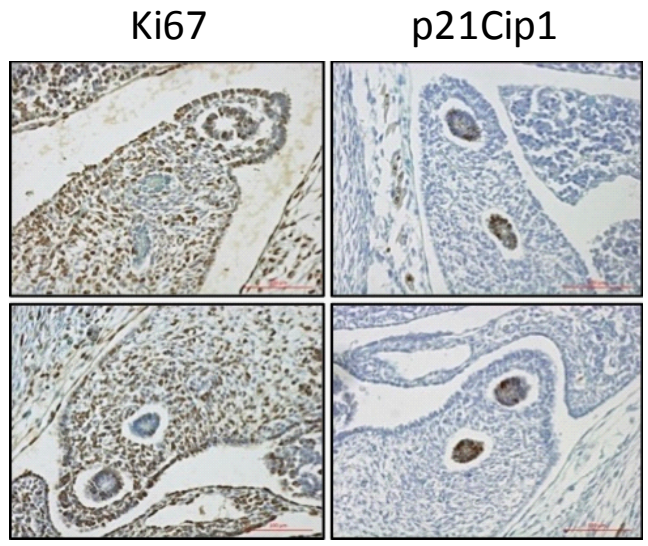

Fig. 2. Expression of SABG, Ki67 and p21Cip1 in WT and Pkd2-null embryos. (A) Sections of WT (top) and Pkd2-null (bottom) embryos previously stained with SABG and marked for the expression of Ki67 (left) and p21Cip1 (right) in embryos of E13.5 (left panels) or E14.5 (right panels) showing the endolymphatic sac area. (B) Same analysis on areas showing the mesonephric tubules. 
result, and given the description of cellular senescence in embryos, alterations in this process during development will undoubtedly contribute to developmental syndromes. We need to carry on doing further work to identify developmental syndromes associated with defects in cellular senescence to better understand the bases of these pathologies and to try to develop appropriate therapies.

\section{Materials and Methods}

\section{Mice}

$P k d 2$ deficient embryos were obtained by crossing heterozygous mice (Wu et al., 1998) to obtain litters representing null and WT genotypes. Genotyping was done as published using DNA extracted from the yolk sacs. Embryos were re-genotyped using DNA extracted from paraffin blocks after histological and immunohistochemical analysis. Animals were kept under SPF conditions and all experiments were approved by the Santiago de Compostela University Bioethics Committee (protocol number 15005AE/07/01/02/05C/AVF2) in compliance with Principles of Laboratory Animal Care of national laws.

\section{Senescence-associated beta-galactosidase staining}

Whole mount Senescence-Associated beta-Galactosidase (SA $\beta G$ ) staining was performed on E13.5 or E14.5 embryos derived from crosses of $P k d 2$ heterozygotic animals (a total of 4 WT and 3 null embryos). After extracting the uterine horns we separated each embryo from its placenta and embryonic sac and fixed them for $25 \mathrm{~min}$ (room temperature) in $2 \%$ formaldehyde $/ 0.2 \%$ glutaraldehyde. After fixation, embryos were washed and incubated overnight at $37^{\circ} \mathrm{C}$ with fresh $S A \beta G$ staining solution: $1 \mathrm{mg}$ of 5-bromo-4-chloro-3-indolyl beta-D-galactoside (X-Gal) per $\mathrm{mL}$ (Fisher Scientific), $40 \mathrm{mM}$ citric acid/sodium phosphate $\mathrm{pH} 5.5,5 \mathrm{mM} \mathrm{K}_{3} \mathrm{Fe}[\mathrm{CN}]_{6}$, $5 \mathrm{mM} \mathrm{K}_{4} \mathrm{Fe}[\mathrm{CN}]_{6}, 150 \mathrm{mM} \mathrm{NaCl}$, and $2 \mathrm{mM} \mathrm{MgCl}_{2}$ (Dimri et al., 1995). Stained embryos were photographed on a magnifying glass, dehydrated in ethanol and embedded in paraffin. Blocks were serially sectioned at $5 \mu \mathrm{m}$ until the first blue stained section was observed. H\&E staining was performed to confirm the presence of the desired organs (i.e. mesonephros and endolymphatic sac) and consecutive sections were obtained until blue staining disappeared for analysis.

\section{Immunohistochemical analysis}

$S A \beta G$ stained sections were further used for immunohistochemical analysis with antibodies against proliferative marker Ki67 (prediluted SP6, Master Diagnostica 0003110QD) and senescence mediator p21Cip1 (HUGO-291 CNIO). The slides of interest were incubated overnight at $37^{\circ} \mathrm{C}$ before being deparaffinized in xylene and rehydrated in a descending series of ethanol solutions. Antigen retrieval was carried out in a PTLink instrument (Dako) and immunoreactive cells were visualized using 3,3-diaminobenzidine tetrahydrochloride plus ( $D A B+$ ) as a chromogen. Sections were counterstained with hematoxylin.

\section{Acknowledgements}

We acknowledge María Otero for expert technical assistance with histological analysis. A.F. is an FPU predoctoral fellow from MECD. M.C. is a "Miguel Servet II" investigator (CPII16/00015). Work in the laboratory of M.C. is funded by an ISCIII and EU-FEDER grant (PI14/00554).

\section{Conflict of interest}

Authors declare no conflict of interest.

\section{References}

BHUNIA AK, PIONTEK K, BOLETTA A, LIU L, QIAN F, XU PN, GERMINO FJ, GERMINO GG (2002). PKD1 induces p21(waf1) and regulation of the cell cycle via direct activation of the JAK-STAT signaling pathway in a process requiring PKD2. Cell 109: 157-168.

COLLADO M, BLASCO MA, SERRANO M (2007). Cellular Senescence in Cancer and Aging. Cell 130: 223-233.

COLLADO M, SERRANO M (2010). Senescence in tumours: evidence from mice and humans. Nat Rev Cancer 10: 51-57.

CORNEC-LE GALL E, AUDRÉZET M-P, RENAUDINEAU E, HOURMANT M, CHARASSE C, MICHEZ E, FROUGET T, VIGNEAU C, DANTAL J, SIOHAN P, et al., (2017). PKD2 -Related Autosomal Dominant Polycystic Kidney Disease: Prevalence, Clinical Presentation, Mutation Spectrum, and Prognosis. Am J Kidney Dis 70: 476-485.

DAVIDSONAJ (2008). Mouse kidney development. Stemb (Harvard Stem Cell Institute).

DIMRI GP, LEE X, BASILE G, ACOSTA M, SCOTT G, ROSKELLEY C, MEDRANO EE, LINSKENS M, RUBELJ I, PEREIRA-SMITH O (1995). A biomarker that identifies senescent human cells in culture and in aging skin in vivo. Proc Natl Acad Sci USA 92: 9363-9367.

GABOW PA (1993). Autosomal dominant polycystic kidney disease. Am J Kidney Dis 22: 511-512.

GRIMM DH, KARIHALOO A, CAI Y, SOMLO S, CANTLEY LG, CAPLAN MJ (2006). Polycystin-2 Regulates Proliferation and Branching Morphogenesis in Kidney Epithelial Cells. J Biol Chem 281: 137-144.

LIX, LUOY, STARREMANS PG, MCNAMARACA, PEI Y, ZHOU J (2005). Polycystin-1 and polycystin-2 regulate the cell cycle through the helix-loop-helix inhibitor Id2. Nat Cell Biol 7: 1202-1212.

MUÑOZ-ESPÍN D, CAÑAMERO M, MARAVERA, GÓMEZ-LÓPEZG, CONTRERAS J, MURILLO-CUESTAS, RODRÍGUEZ-BAEZAA, VARELA-NIETO I, RUBERTE $\mathrm{J}$, COLLADO M, SERRANO M (2013). Programmed cell senescence during mammalian embryonic development. Cell 155: 1104-1118.

MUÑOZ-ESPÍN D, SERRANO M (2014). Cellular senescence: from physiology to pathology. Nat Rev Mol Cell Biol 15: 482-496.

PÉREZ-GARIJO A, STELLER H (2014). The benefits of aging: cellular senescence in normal development. EMBO J 33: 99-100.

QIAN F, WATNICK TJ, ONUCHIC LF, GERMINO GG (1996). The molecular basis of focal cyst formation in human autosomal dominant polycystic kidney disease type I. Cell 87: 979-987.

SAINIO K (2003). Development of the mesonephric kidney. In The kidney. From normal development to congenital disease (Eds C Vize, AS Woolf, and JBL Bard). Academic Press, London, pp. 75-86.

STORER M, MAS A, ROBERT-MORENO A, PECORARO M, ORTELLS MC, DI GIACOMO V, YOSEF R, PILPEL N, KRIZHANOVSKY V, SHARPE J, KEYES WM (2013). Senescence Is a Developmental Mechanism that Contributes to Embryonic Growth and Patterning. Cell 155: 1119-1130.

VAZQUEZ MD, BOUCHET P, MALLET JL, FOLIGUET B, GÉRARD H, LEHEUP B (1998). 3D reconstruction of the mouse's mesonephros. Anat Histol Embryol 27: 283-287.

WATNICK TJ, TORRES VE, GANDOLPH MA, QIAN F, ONUCHIC LF, KLINGER KW, LANDES G, GERMINO GG (1998). Somatic mutation in individual liver cysts supports a two-hit model of cystogenesis in autosomal dominant polycystic kidney disease. Mol Cell 2: 247-251.

WU G, D'AGATI V, CAI Y, MARKOWITZ G, PARK JH, REYNOLDS DM, MAEDA Y, LE TC, HOU H, KUCHERLAPATI R, EDELMANN W, SOMLO S (1998). Somatic inactivation of $\mathrm{Pkd} 2$ results in polycystic kidney disease. Cell 93: 177-188. 


\section{Further Related Reading, published previously in the Int. J. Dev. Biol.}

Cellular senescence in tissue repair: every cloud has a silver lining Maximina H. Yun

Int. J. Dev. Biol. (2018) 62: 591-604

Interdigital tissue regression in the developing limb of vertebrates

Carlos I. Lorda-Diez, Juan A. Montero, Juan A. Garcia-Porrero and Juan M. Hurle

Int. J. Dev. Biol. (2015) 59: 55-62

Mpl receptor defect leads to earlier appearance of hematopoietic cells/hematopoietic stem cells in the Aorta-Gonad-Mesonephros region, with increased apoptosis

Maud Fleury, Laurence Petit-Cocault, Denis Clay and Michèle Souyri

Int. J. Dev. Biol. (2010) 54: 1067-1074

https://doi.org/10.1387/ijdb.103104mf

Mesonephric kidney--a stem cell factory?

$\mathrm{K}$ Sainio and A Raatikainen-Ahokas

Int. J. Dev. Biol. (1999) 43: 435-439

http://www.intjdevbiol.com/web/paper/10535320

Differentiated aspect of female and male mouse mesonephroi

M D Vazquez, P Bouchet, B Foliguet, H Gérard, J L Mallet and B Leheup

Int. J. Dev. Biol. (1998) 42: 621-624

http://www.intjdevbiol.com/web/paper/9694634

Towards a molecular anatomy of the Xenopus pronephric kidney

A W Brändli

Int. J. Dev. Biol. (1999) 43: 381-395

http://www.intjdevbiol.com/web/paper/10535314

Distribution of TNF alpha-like proteins correlates with some regions of programmed cell death in the chick embryo

M A Wride, P H Lapchak and E J Sanders

Int. J. Dev. Biol. (1994) 38: 673-682

http://www.intjdevbiol.com/web/paper/7779688

The role of the mesonephros in cell differentiation and morphogenesis of the mouse fetal testis

$\mathrm{H}$ Merchant-Larios, N Moreno-Mendoza and M Buehr

Int. J. Dev. Biol. (1993) 37: 407-415

http://www.intjdevbiol.com/web/paper/8292535

5 yr ISI Impact Factor $(2016)=2.421$
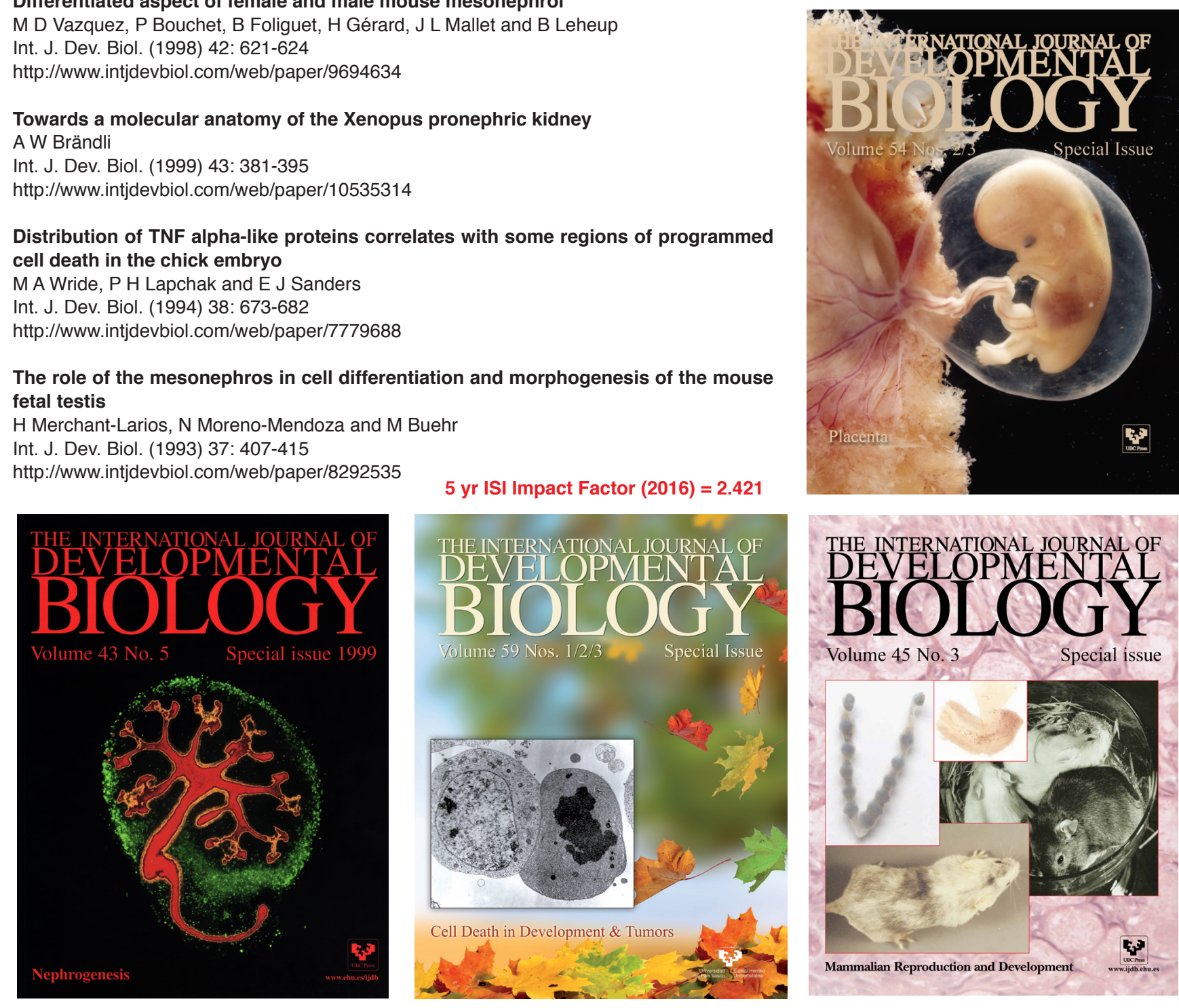